УДК 342.9

DOI: $10.21779 / 2500-1930-2019-34-2-86-92$

\title{
А.3. Арсланбекова
}

\section{Проблемы применения административного принуждения}

Дагестанский государственный университет; Россия, 367001, г. Махачкала, ул. М. Гаджиева, 43a; tanima22@mail.ru

Исполнительные органы используют в своей деятельности различные методы регулирования общественных отношений, среди которых можно выделить административное принуждение. Институт административного принуждения развивается в зависимости от проводимой государственной политики, однако в науке отсутствует единый подход к пониманию проблем ее реализации. Это вызвано изданием большого количества противоречащих друг другу нормативных актов, закрепляющих меры административного принуждения.

Цели статьи - рассмотрение некоторых проблем применения административного принуждения и разработка предложений, направленных на их разрешение.

При написании статьи были использованы следующие методы исследования: логический, формально-юридический, сравнительно-правовой, правового моделирования и анализа.

В заключение делается вывод о необходимости принятия единого федерального закона, который бы предусматривал одинаковые основания и порядок применения пресекательных мер различными субъектами.

Ключевые слова: административное принуждение, военнослужаший, поличия, досмотр транспортного средства, вскрытие транспортного средства, оружие.

Исполнительные органы используют в своей деятельности различные методы регулирования общественных отношений, среди которых можно выделить административное принуждение. Институт административного принуждения развивается в зависимости от проводимой государственной политики, однако в науке отсутствует единый подход к пониманию проблем ее реализации [1, с. 73-74]. Это вызвано также изданием большого количества противоречащих друг другу нормативных актов, закрепляющих меры административного принуждения. Недостатки законодательства пагубно влияют на качество регулирования общественных отношений, возникающих в сфере государственного управления.

В последнее время исполнительные органы чаще используют не основной метод государственного управления - убеждение, а дополнительный - принуждение. К сожалению, должностные лица исполнительных органов, применяющие меры административного принуждения, в недостаточной мере подготовлены и квалифицированы. Об этом свидетельствуют многочисленные жалобы граждан на действия исполнительных органов по применению принудительных мер, направленные Уполномоченному по правам человека в РФ [2].

Рассмотрим основные проблемы, связанные с применением административного принуждения.

86 Вестник Дагестанского государственного университета

Серия 3. Общественные науки. 2019. Том 34. Вып. 2 
1. Нормативная база, закрепляющая порядок применения административного принуждения, не лишена недостатков, в ней присутствуют противоречия, дублирование и несогласованность. В связи с этим у правоприменителей возникают проблемы при применении ограничительных мер к гражданам.

Недостатки нормативных актов, закрепляющих меры административного принуждения, создают сложности в правильном толковании и в применении правовых норм. К сожалению, нормативные акты не закрепляют детальную последовательность действий должностных лиц при осуществлении административных процедур. Встречаются случаи, когда нормативные акты запутывают действия должностных лиц при применении ими мер административного принуждения. Следует также отметить, что в настоящее время и судебная практика не имеет общей позиции по этим вопросам.

Д.А. Керимов пишет, что такая ситуация «...порождает многочисленные запросы, влечет изменения и дополнения, различные толкования и разъяснения, вызывает непроизводительную трату времени, сил и энергии, одновременно является питательной почвой для бюрократической волокиты, позволяет извращать смысл закона и неправильно его применять» [3, с. 133].

В.Р. Кисин отмечает, что «неопределенность характера действий, составляющих содержание некоторых мер обеспечения производства по делам об административных правонарушениях, конкретных целей и (или) оснований их применения представляется одним из существенных недостатков, негативно влияющих на правоприменение. Эта неопределенность правового регулирования не восполняется и доктринальным толкованием, которое не отличается единством взглядов на содержание и цели данного процессуального действия» [4].

Актуальность данной проблемы можно установить на примере применения досмотра транспортных средств, осуществляемых органами полиции. К сожалению, эта мера регулируется различными нормативными актами. Так, согласно ч. 1 ст. 27.9 КоАП РФ «Досмотр транспортного средства любого вида, то есть обследование транспортного средства, проводимое без нарушения его конструктивной целостности, осуществляется в целях обнаружения орудий совершения либо предметов административного правонарушения».

Досмотр транспортного средства сотрудниками полиции осуществляется на основе Административного регламента, утвержденного Приказом МВД России от 23 августа 2017 г. № 664 [5]. Так, согласно п. 210 Административного регламента сотрудник полиции «в случае обнаружения в ходе досмотра транспортного средства достаточных данных, указывающих на наличие события административного правонарушения, при отсутствии обстоятельств, исключающих производство по делу об административном правонарушении, возбуждает дело об административном правонарушении».

Согласно п. 2 ч. 4 ст. 28.1 КоАП РФ «дело об административном правонарушении считается возбужденным с момента составления протокола о применении мер обеспечения производства по делу об административном правонарушении, предусмотренных ст. 27.1 КоАП РФ». В соответствии с ч. 5 ст. 27.9 КоАП РФ при досмотре транспортного средства «составляется протокол либо делается соответствующая запись в протоколе об административном задержании». 
Следовательно, полицейский, проводящий досмотр транспортного средства, фактически возбуждает производство по делу об административном правонарушении, которое оформляется протоколом об административном правонарушении, или выносит постановление о прекращении производства по делу об административном правонарушении (п. 1 ч. 1.1 ст. 29.9 КоАП РФ). Таким образом, на лицо противоречие норм КоАП РФ п. 210 Административного регламента, что в свою очередь вносит определенную путаницу в действия сотрудника полиции.

Рассмотрим другой пример. Пункт 258 Административного регламента предоставляет полицейскому право на запрещение эксплуатации транспортного средства. Эта мера была исключена из КоАП РФ и заключалась в снятии с транспортного средства государственных регистрационных знаков до устранения причины запрещения эксплуатации транспортного средства [6].

Однако другая пресекательная мера, предусмотренная ч. 1 ст. 27.13 КоАП РФ в виде задержания транспортного средства, под которой понимается «исключение транспортного средства из процесса перевозки людей и грузов путем перемещения его при помощи другого транспортного средства, помещения в ближайшее специально отведенное охраняемое место (на специализированную стоянку) и хранение на специализированной стоянке до устранения причины задержания», противоречит п. 259 Административного регламента, в котором запрещение эксплуатации транспортного средства заключается в прекращении движения транспортного средства до устранения соответствующих неисправностей или условий.

Думается, эти меры не различаются. Пункт 259 Административного регламента соответствует ст. 19 «Основания и порядок запрещения эксплуатации транспортных средств» ФЗ от 10 декабря 1995 г. № 196-ФЗ «О безопасности дорожного движения» [7]. Однако этот закон не закрепляет порядок применения этой меры, а ст. 27.1 КоАП РФ, которая перечисляет все меры обеспечения производства по делу об административном правонарушении, такую меру не называет.

2. В последнее время наметилась тенденция по принятию нормативных актов, которые не содержат четкого порядка применения принудительных мер, что в свою очередь вызывает их неправильное толкование.

Ст. 11 Ф3 от 3 июля 2016 г. № 226-Ф3 «О войсках национальной гвардии РФ» [8] установила такую меру принуждения, как «вскрытие транспортного средства». Однако закон не дает определения этой меры, что вызывает различные мнения как у ученых, так и у практических работников. Одни считают, что вскрытие транспортного средства есть не что иное, как досмотр транспортного средства [9, с. 54], что представляется спорным.

Вскрытие транспортного средства и досмотр транспортного средства имеют разные цели. Так, согласно ч. 1 ст. 27.9 КоАП РФ досмотр транспортного средства может проводиться с целью обнаружения орудия совершения или предмета административного правонарушения. В ч. 1 ст. 11 Ф3 «О войсках национальной гвардии РФ» перечисляются цели, которые преследуются при вскрытии транспортного средства. Они являются пресекательными и могут осуществляться при отсутствии владельца транспортного средства. Однако досмотр транспортного средства осуществляется при наличии понятых, а вскрытие не требует их присутствия.

3. Несогласованность действий различных исполнительных органов при обеспечении режима контртеррористической операции в связи с несовершенством зако- 
нодательства, закрепляющего принудительные меры. Это в свою очередь вызывает проблемы у сотрудников МВД РФ, войск национальной гвардии РФ, Министерства обороны, которые применяют огнестрельное оружие в пресекательных целях.

Военнослужащие Вооруженных сил РФ применяют огнестрельное оружие в условиях контртеррористической операции в соответствии с «Положением о применении Вооруженными силами РФ оружия, боевой техники и специальных средств при участии в проведении контртеррористической операции» [10] (далее - Положение), военнослужащие войск национальной гвардии - в соответствии с Ф3 «О войсках национальной гвардии РФ», а сотрудники полиции - в соответствии с ФЗ «О полиции».

В перечисленных нормативных актах указываются разные основания применения огнестрельного оружия во время проведения контртеррористической операции. Рассмотрим следующие случаи.

1. В соответствии с п. 6 ч. 1 ст. 23 ФЗ «О полиции» сотрудник полиции может использовать огнестрельное оружие для отражения группового или вооруженного нападения на охраняемые им объекты здания.

В соответствии с п. «г» ч. 5 Положения военнослужащий Вооруженных сил также может применить огнестрельное оружие для «отражения нападения либо угрозы нападения на охраняемые объекты, транспортные средства и военнослужащих». Но в Положении не закреплено, что такое нападение является групповым или вооруженным. Согласно п. «в» ч. 5 Положения военнослужащий может применить оружие для «задержания лиц, совершивших (совершающих) нападение на охраняемые объекты, транспортные средства и военнослужащих, в случае оказания ими вооруженного сопротивления или отказа выполнить законное требование о сдаче оружия, если другими способами подавить сопротивление или изъять оружие невозможно».

Военнослужащий войск национальной гвардии может использовать оружие для пресечения попыток лиц незаконно проникнуть на территории (акватории) охраняемых войсками национальной гвардии объектов, а также постов и других мест несения войсками национальной гвардии боевой службы, если невозможно пресечь эти попытки иным способом.

2. Применить оружие можно и в целях остановки транспортного средства. Согласно п. 1 ч. 3 ст. 23 Ф3 «О полиции» полицейские могут применить огнестрельное оружие «для остановки транспортного средства путем его повреждения, если управляющее им лицо отказывается выполнить неоднократные требования сотрудника полиции об остановке и пытается скрыться, создавая угрозу жизни и здоровью граждан».

Согласно п. 7 ст. 21 ФЗ «О войсках национальной гвардии РФ» военнослужащий вправе применить огнестрельное оружие «если водитель (капитан) отказывается остановиться, несмотря на законные требования сотрудников полиции или военнослужащих (сотрудников) войск национальной гвардии», т. е. для применения оружия не требуются ни неоднократность требований, ни создание угрозы жизни и здоровью граждан.

В соответствии с пп. «е» п. 5 Положения военнослужащий Вооруженных сил РФ с целью остановки транспортного средства вправе не только его повредить, но и 
уничтожить, если водитель отказывается остановиться, несмотря на законные требования.

Как представляется, такая несогласованность вызывает серьезные проблемы при применении пресекательных мер на практике, поэтому необходимо принять единый федеральный закон, который бы предусматривал одни основания и порядок применения пресекательных мер различными субъектами.

\section{Литература}

1. Алдеров И.С. Проблемы классификации мер административного принуждения в области пожарной безопасности // Юридический вестник ДГУ. - 2018. - № 2.

2. Доклад Уполномоченного по правам человека в Российской Федерации // Российская газета. - 2016. - 24 марта; 2017. - 17 мая.

3. Керимов Д.А. Проблемы общей теории государства и права. - М.: СГУ, 2000.

4. Кисин B.P. Меры обеспечения производства по делам об административных правонарушениях: юридическая природа и недостатки правового регулирования // Административное право и процесс. - 2018. - № 1.

5. Приказ МВД России от 23 августа 2017 г. № 664 «Об утверждении Административного регламента исполнения Министерством внутренних дел Российской Федерации государственной функции по осуществлению федерального государственного надзора за соблюдением участниками дорожного движения требований законодательства РФ в области безопасности дорожного движения»// Российская газета. - 2017. - 13 октября.

6. Федеральный закон от 14 октября 2014 г. № 307-Ф3 «О внесении изменений в Кодекс Российской Федерации об административных правонарушениях и отдельные законодательные акты РФ и о признании утратившими силу отдельных положений законодательных актов РФ в связи с уточнением полномочий государственных органов и муниципальных органов в части осуществления государственного контроля (надзора) и муниципального контроля» // СЗ РФ. - 2014. - № 42. - Ст. 5615.

7. СЗ РФ.- 1995. - № 50. - Ст. 4873.

8. СЗ РФ. - 2016. - № 27 (Ч. І). - Ст. 4159.

9. Сальников В.П., Борисов О.С., Кондрат Е.Н. Комментарий к Федеральному закону от 3 июля 2016 г. № 226-Ф3 «О войсках национальной гвардии Российской Федерации». - М., 2016.

10. Постановление Правительства РФ от 6 июня 2007 г. № 352 «О мерах по реализации Федерального закона «О противодействии терроризму» (вместе с «Положением о применении Вооруженными силами РФ оружия, боевой техники и специальных средств при участии в проведении контртеррористической операции») // С3 РФ. - 2007. - № 24. - Ст. 2921.

\section{Literatura}

1. Alderov I.S. Problemyi klassifikatsii mer administrativnogo prinuzhdeniya v oblasti pozharnoy bezopasnosti // Yuridicheskiy vestnik DGU. - 2018. - № 2

2. Doklad Upolnomochennogo po pravam cheloveka v Rossiyskoy Federatsii // Rossiyskaya gazeta. - 2016. - 24 marta; 2017. - 17 maya.

3. Kerimov D.A. Problemyi obschey teorii gosudarstva i prava. - M.: SGU, 2000. 
4. Kisin V.R. Meryi obespecheniya proizvodstva po delam ob administrativnyih pravonarusheniyah: yuridicheskaya priroda i nedostatki pravovogo regulirovaniya // Administrativnoe pravo i protsess. - 2018. - № 1 .

5. Prikaz MVD Rossii ot 23 avgusta 2017 g. № 664 «Ob utverzhdenii Administrativnogo reglamenta ispolneniya Ministerstvom vnutrennih del Rossiyskoy Federatsii gosudarstvennoy funktsii po osuschestvleniyu federalnogo gosudarstvennogo nadzora za soblyudeniem uchastnikami dorozhnogo dvizheniya trebovaniy zakonodatelstva RF v oblasti bezopasnosti dorozhnogo dvizheniya» // Rossiyskaya gazeta. - 2017. - 13 oktyabrya

6. Federalnyiy zakon ot 14 oktyabrya 2014 g. № 307-FZ «O vnesenii izmeneniy v Kodeks Rossiyskoy Federatsii ob administrativnyih pravonarusheniyah i otdelnyie zakonodatelnyie aktyi RF i o priznanii utrativshimi silu otdelnyih polozheniy zakonodatelnyih aktov RF v svyazi s utochneniem polnomochiy gosudarstvennyih organov i munitsipalnyih organov $v$ chasti osuschestvleniya gosudarstvennogo kontrolya (nadzora) i munitsipalnogo kontrolya» // SZ RF. - 2014. - № 42. - St. 5615.

7. SZ RF.- 1995. - № 50. - St. 4873

8. SZ RF. - 2016. - № 27 (Ch. I). - St. 4159.

9. Salnikov V.P., Borisov O.S., Kondrat E.N. Kommentariy k Federalnomu zakonu ot 3 tyulya 2016 g. № 226-FZ «O voyskah natsionalnoy gvardii Rossiyskoy Federatsii». M., 2016.

10. Postanovlenie Pravitelstva RF ot 6 iyunya 2007 g. № 352 «O merah po realizatsii Federalnogo zakona «O protivodeystvii terrorizmu» (vmeste $\mathrm{s}$ «Polozheniem o primenenii Vooruzhennyimi silami RF oruzhiya, boevoy tehniki i spetsialnyih sredstv pri uchastii V provedenii kontrterroristicheskoy operatsii») // SZ RF. - 2007. - № 24. - St. 2921.

Поступила в редакичюю 25 марта 2019 г.

UDC 342.9

DOI: $10.21779 / 2500-1930-2019-34-2-86-92$

\section{Problems of application of administrative enforcement}

\section{A.Z. Arslanbekova}

Dagestan State University; Russia, 367001, Makhachkala, M. Gadzhiev st., 43a; tanima22@mail.ru

The Executive bodies use a wide range of different methods of regulating social relations in the course of their activities, among which administrative enforcement can be singled out. The Institute of administrative enforcement develops depending on the state policy, but there is no unified approach to understanding the problems of its implementation in scientific community. This is due 
to the publication of a large number of conflicting regulations that enshrine measures of administrative enforcement.

The aim of the article is to consider some of the problems of administrative enforcement and to develop proposals aimed at their solutions.

When writing the article the following research methods were used: logical, formal legal, comparative legal, method of legal modeling and analysis.

The authors draw conclusions about the necessity to adopt a single Federal law, which would provide for the same grounds and procedure for the application of preventive measures by different entities.

Keyword: administrative coercion, soldier, Police, inspection of the vehicle, opening the vehicle weapons.

Received 25 March, 2019 